\title{
DOUBLE FILLET WELDING OF CARBON STEEL T-JOINT BY DOUBLE CHANNEL SHIELDING GAS METAL ARC WELDING METHOD USING METAL CORED WIRE
}

\begin{abstract}
Low carbon steel material and T-joints are frequently used in ship building and steel constructions. Advantages such as high deposition rates, high quality and smooth weld metals and easy automation make cored wires preferable in these industries. In this study, low carbon steel materials with web and flange thicknesses of $6 \mathrm{~mm}, 8 \mathrm{~mm}$ and $10 \mathrm{~mm}$ were welded with conventional GMAW and double channel shielding gas metal arc welding (DMAG) method to form double fillet T-joints using metal cored wire. The difference between these two methods were characterized by measurements of mean welding parameters, Vickers hardness profiles, weld bead and HAZ geometry of the joints and thermal camera temperature measurements. When weld bead and HAZ geometries are focused, it was seen filler metal molten area increased and base metal molten area decreased in DMAG of low carbon steel. When compared with traditional GMAW, finer and acicular structures in weld metal and more homogenous and smaller grains in HAZ are obtained with double channel shielding gas metal arc welding.
\end{abstract}

Keywords: Double channel torch; low carbon steel; metal cored wire; T-joint; microstructure

\section{Introduction}

T-joints are used in manufacturing and heavy industries widely and they are generally formed with gas metal arc welding (GMAW) using either solid or cored wires. Due to their high deposition rates, cored wires shorten manufacturing cycles and are extensively utilized in these industries. GMAW has been researched extensively by a number of researchers unlike double channel shielding gas metal arc welding (DMAG) method. Principle of DMAG has been explained by Mert et al. [1]. Schematic representation of DMAG is shown in Fig. 1.

Literature research shows limited number of studies on independent flow of dual shielding gas supply in gas metal arc and gas tungsten arc welding methods. Some researchers have investigated supply of double shielding gas in gas tungsten arc (GTA) welding and they have studied double shielded GTA method to improve weld penetration as well as the effect of flow ratio between inner and outer layers of the shielding gas on the fusion zone profile. They have also researched critical oxygen content in the weld pool in double shielded GTA welding to increase weld depth and also weld pool shape variations and electrode oxidation and protection [3-7].

In contrast, some other researchers have investigated DMAG method. They have focused on seam geometry, metal transfer, spatter loss and porosity in DMAG welding using solid and cored wires [8-9]. Other researchers have also studied spatter amounts in nozzles of DMAG welding torches [10-11]. DMAG welding of aluminum has also been investigated [12]. Shielding gas flow in inner and outer channels of DMAG torch has been researched and reported flow to be less turbulent compared with single channel flow [13]. DMAG welding of austenitic stainless steel with $10 \mathrm{~mm}$ thickness using cored wire to form double fillet

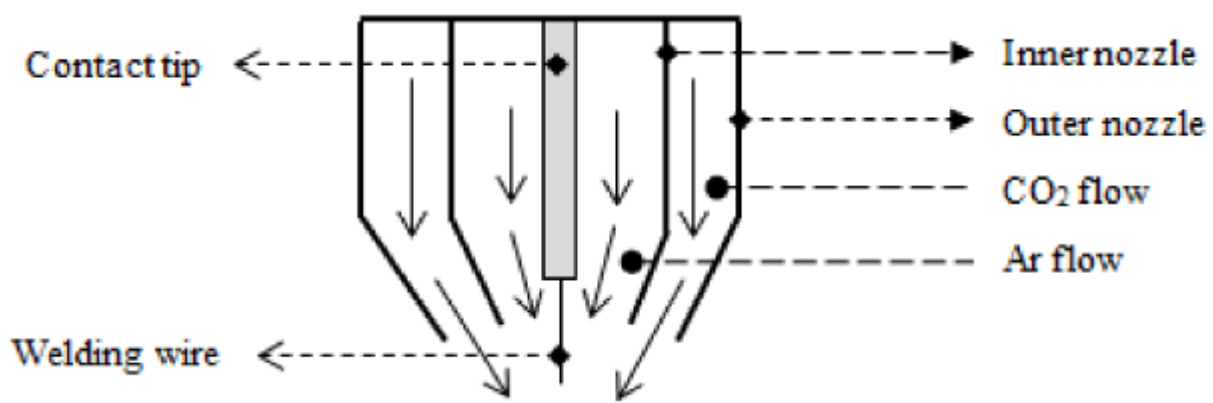

Fig. 1. Schematic representation of DMAG method [2]

\footnotetext{
* YILDIZ TECHNICAL UNIVERSITY, ISTANBUL, TURKEY

\# Corresponding author: tmert@yildiz.edu.tr
} 
T-joint has been investigated by Mert et al. [1].

In this paper, in order to form double fillet welded T-joints of low carbon steel with different thicknesses, i.e. $6 \mathrm{~mm}, 8 \mathrm{~mm}$ and $10 \mathrm{~mm}$, DMAG and conventional GMAW were utilized using metal cored wire. Mean welding parameters and heat input, thermal camera temperature measurements and Vickers hardness profiles, weld metal, HAZ, base metal molten and filler metal molten area measurements as well as microstructures were compared between these two methods.

\section{Experimental}

Low carbon steel material with $6 \mathrm{~mm}, 8 \mathrm{~mm}$ and $10 \mathrm{~mm}$ thicknesses was used along with metal cored wire (EN ISO 17632: T 423 M M H8) with 1.2 mm diameter and double channel shielding gas metal arc welding torch in order to form unrestricted $\mathrm{T}$ joints with $100 \mathrm{~mm} \times 200 \mathrm{~mm}$ web and $200 \mathrm{~mm} \times 200 \mathrm{~mm}$ flange. Chemical composition of base metal and filler metal are given in Table 1 . Power source, wire feed unit, torch manipulator, DMAG torch, gas mixers were same as the ones used in previous studies [1, 2, 11]. Experimental setup is shown in Fig. 2.

TABLE 1

Chemical compositions of low carbon steel S235JR (EN 10025) with $6 \mathrm{~mm}, 8 \mathrm{~mm}$ and $10 \mathrm{~mm}$ thicknesses and metal cored filler metal (\% wt.)

\begin{tabular}{|c|c|c|c|c|c|c|c|}
\hline \hline Material & \%C & \%Mn & \%Si & \%P & \%S & \%Cu & \%Al \\
\hline S235JR [6 mm] & 0.060 & 0.550 & 0.140 & 0.013 & 0.022 & 0.050 & 0.034 \\
\hline S235JR [8 mm] & 0.077 & 0.689 & 0.137 & 0.011 & 0.006 & 0.007 & 0.040 \\
\hline S235JR [10 mm] & 0.094 & 0.729 & 0.191 & 0.016 & 0.004 & 0.017 & 0.048 \\
\hline $\begin{array}{c}\text { Metal cored filler } \\
\text { metal }\end{array}$ & 0.05 & 1.50 & 0.65 & $<0.01$ & $<0.02$ & - & - \\
\hline
\end{tabular}

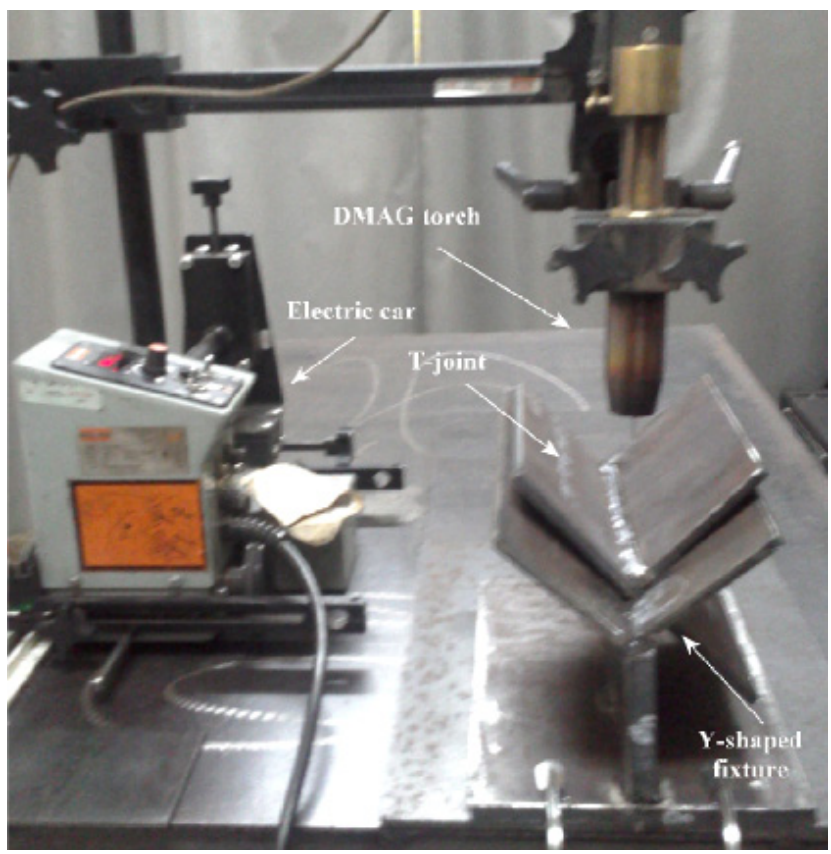

Fig. 2. Experimental setup [1]
Total shielding gas flow rate was $15 \mathrm{~L} \mathrm{~min}^{-1}$. Shielding gases used were $40 \% \mathrm{Ar}-60 \% \mathrm{CO}_{2} \mathrm{mix}$ for $6 \mathrm{~mm}$ thickness, $50 \% \mathrm{Ar}-50 \% \mathrm{CO}_{2}$ mix for $8 \mathrm{~mm}$ thickness and $60 \% \mathrm{Ar}-40 \% \mathrm{CO}_{2}$ mix for $10 \mathrm{~mm}$ thickness in conventional GMAW, whereas in DMAG method, corresponding to the same flow rate as in GMAW, shielding gas flow in inner channel of the double shielding gas torch was $6 \mathrm{~L} \mathrm{~min}^{-1} \mathrm{Ar}$ and $9 \mathrm{~L} \mathrm{~min}^{-1} \mathrm{CO}_{2}$ in outer channel, 7.5 $\mathrm{L} \mathrm{min}^{-1} \mathrm{Ar}$ in inner channel and 7.5 $\mathrm{L} \mathrm{min}^{-1} \mathrm{CO}_{2}$ in outer channel, $9 \mathrm{~L} \mathrm{~min}^{-1} \mathrm{Ar}$ in inner channel and $6 \mathrm{~L} \mathrm{~min}^{-1} \mathrm{CO}_{2}$ in outer channel, respectively.

Preliminary tests were realized in order to obtain calculated design leg lengths of $4.5 \mathrm{~mm}, 6 \mathrm{~mm}$ and $7.5 \mathrm{~mm}$ for $6 \mathrm{~mm}, 8 \mathrm{~mm}$ and $10 \mathrm{~mm}$ thicknesses, respectively. When desired weld sizes were achieved, parameter settings were recorded (i.e., wire feed rates of $9.55 \mathrm{~m} \mathrm{~min}^{-1}, 10.51 \mathrm{~m} \mathrm{~min}^{-1}, 12.01 \mathrm{~m} \mathrm{~min}^{-1}$; welding speeds of $47 \mathrm{~cm} \mathrm{~min}^{-1}, 43 \mathrm{~cm} \mathrm{~min}^{-1}, 34 \mathrm{~cm} \mathrm{~min}^{-1}$, respectively). Electrode extension of $19 \mathrm{~mm}$ was fixed during the tests.

During welding, temperatures were recorded with FLIR A320 thermal camera (Fig. 3). Temperature recording via thermal camera lasted around two minutes. Thermal camera temperature measurement points are shown in Figure 3 and these points (i.e. points 6, 7, and 8) are in the middle of the joint and in HAZ and its vicinity. Closest point to weld seam is point 6 . There is $3 \mathrm{~mm}$ distance between each apparent temperature measurement points.

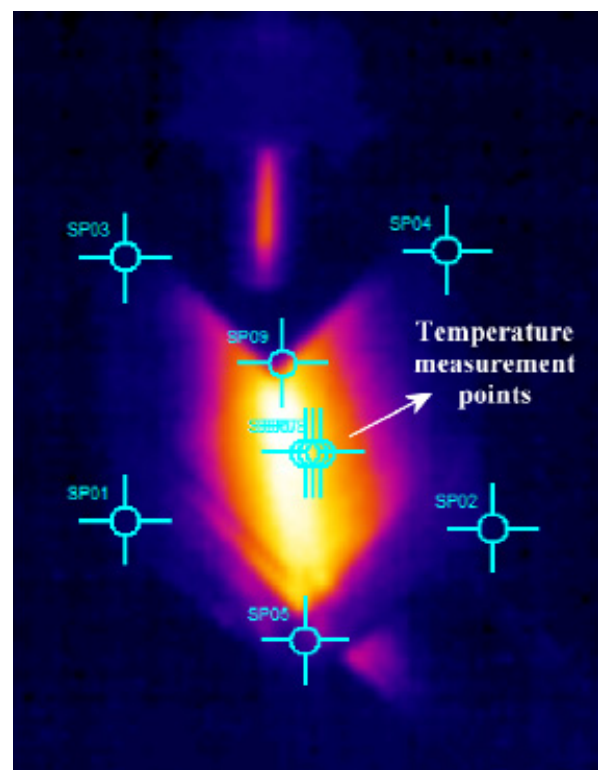

Fig. 3. Apparent temperature measurement points for T-fillet joints

Small T-fillet macro and hardness samples involving base metal, weld metal and HAZ were extracted from T-fillet welded joints after welding was finished. Samples ground with $\mathrm{SiC}$ sand papers in several steps and then polished with diamond paste. Before Vickers hardness measurements, samples were micro etched. 5 hardness measurements from each zone (i.e. base metal, HAZ, weld metal, HAZ and base metal) with a total of 25 measurements for each welded sample were realized. There was $0.5 \mathrm{~mm}$ distance between measurement points for base metal and weld metal hardness measurements; whereas the distance 
between two measurement points was $0.25 \mathrm{~mm}$ for HAZ because it was narrower compared with base metal and weld metal. Fig. 4 presents hardness measurement locations in the joint. Completing these measurements, samples were macro etched and then, weld metal, HAZ, base metal molten and filler metal molten area measurements were realized via computer software.

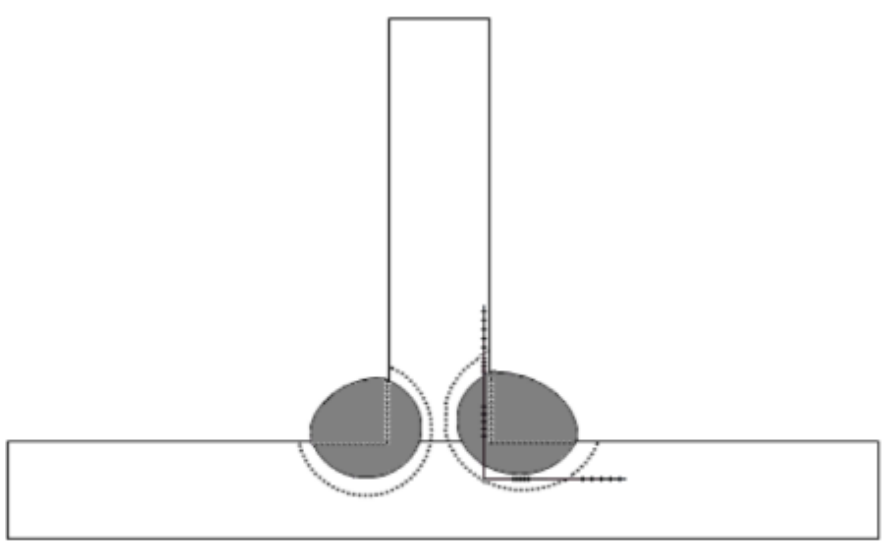

Fig. 4. Hardness measurement locations in the joint

\section{Results and discussion}

It was observed that generally mean currents were higher and mean voltages were lower in DMAG compared with conventional GMAW but differences were more significant in current values (Table 2). Total heat inputs in two passes were generally $3 \%$ to $6 \%$ higher in DMAG compared with traditional GMAW, mainly because of higher current values recorded.

Fig. 5 introduces apparent temperatures measured in T-fillet joint with $6 \mathrm{~mm}$ thickness, for points 6,7 and 8 were $1216^{\circ} \mathrm{C}$, $735^{\circ} \mathrm{C}$ and $480^{\circ} \mathrm{C}$ with the use of traditional GMAW (40\%Ar$60 \% \mathrm{CO}_{2}$ ) and $823^{\circ} \mathrm{C}, 528^{\circ} \mathrm{C}$ and $448^{\circ} \mathrm{C}$ with the use of DMAG (6 $\mathrm{L} \mathrm{min}^{-1} \mathrm{Ar}-9 \mathrm{~L} \mathrm{~min}^{-1} \mathrm{CO}_{2}$ ), respectively. Cooling of points 6,7 , and 8 down to $400^{\circ} \mathrm{C}$ from maximum temperatures reached
TABLE 2

Mean welding parameters, heat input energies and total heat inputs for double fillet welded T-joints using metal cored wire

\begin{tabular}{|c|c|c|c|c|c|c|}
\hline 总 & $\begin{array}{l}\text { Shielding } \\
\text { Gas Supply }\end{array}$ & $\underset{\Xi}{\Xi}$ & 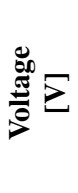 & 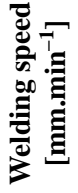 & 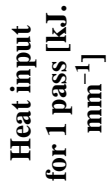 & 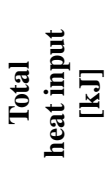 \\
\hline \multirow[b]{2}{*}{6} & $40 \% \mathrm{Ar}-60 \% \mathrm{CO}_{2}$ & 225 & 30.9 & 470 & 0.797 & 318.9 \\
\hline & $\begin{array}{l}\text { DMAG }-6 \mathrm{~L} \mathrm{~min}{ }^{-1} \\
\mathrm{Ar}-9 \mathrm{~L} \mathrm{~min}^{-1} \mathrm{CO}_{2}\end{array}$ & 224 & 30.5 & 470 & 0.785 & 314 \\
\hline \multirow[b]{2}{*}{8} & $50 \% \mathrm{Ar}-50 \% \mathrm{CO}_{2}$ & 235 & 29.6 & 430 & 0.872 & 348.8 \\
\hline & $\begin{array}{l}\text { DMAG - 7.5 L min } \\
\text { Ar }-7.5 \mathrm{~L} \mathrm{~min}{ }^{-1} \mathrm{CO}_{2}\end{array}$ & 252 & 29.2 & 430 & 0.924 & 369.5 \\
\hline \multirow[b]{2}{*}{10} & $60 \% \mathrm{Ar}-40 \% \mathrm{CO}_{2}$ & 267 & 31.2 & 340 & 1.321 & 528.4 \\
\hline & $\begin{array}{l}\text { DMAG - } 9 \mathrm{~L} \mathrm{~min}^{-1} \\
\mathrm{Ar}-6 \mathrm{~L} \mathrm{~min}^{-1} \mathrm{CO}_{2}\end{array}$ & 278 & 31 & 340 & 1.364 & 545.6 \\
\hline
\end{tabular}

took 28.7 s, $27.1 \mathrm{~s}$ and $18.8 \mathrm{~s}$ with the use of traditional GMAW and 27 s, 21 s and $3.9 \mathrm{~s}$ with the use of DMAG, respectively. As a consequence, calculated cooling rates of these apparent temperature measurement points were $28.4^{\circ} \mathrm{C} \mathrm{s}^{-1}, 12.4^{\circ} \mathrm{C} \mathrm{s}^{-1}$ and $4.3^{\circ} \mathrm{C} \mathrm{s}^{-1}$ with the use of conventional GMAW and $15.7^{\circ} \mathrm{C} \mathrm{s}^{-1}$, $6.1^{\circ} \mathrm{C} \mathrm{s}^{-1}$ and $12.3^{\circ} \mathrm{C} \mathrm{s}^{-1}$ with the use of DMAG, respectively.

Fig. 6 presents Vickers hardness graph for T-fillet joints with $6 \mathrm{~mm}$ thickness welded with DMAG - $6 \mathrm{~L} \mathrm{~min}^{-1} \mathrm{Ar}-9 \mathrm{~L}$ $\min ^{-1} \mathrm{CO}_{2}$ and $40 \% \mathrm{Ar}-60 \% \mathrm{CO}_{2}$. It can be seen weld metal and HAZ hardness values were slightly higher with DMAG.

Fig. 7 shows apparent temperatures measured in T-fillet joint with $8 \mathrm{~mm}$ thickness, for points 6,7 and 8 were $951^{\circ} \mathrm{C}$, $555^{\circ} \mathrm{C}$ and $412^{\circ} \mathrm{C}$ with the use of traditional GMAW (50\%Ar$50 \% \mathrm{CO}_{2}$ ) and $1125^{\circ} \mathrm{C}, 609^{\circ} \mathrm{C}$ and $425^{\circ} \mathrm{C}$ with the use of DMAG (7.5 L min ${ }^{-1} \mathrm{Ar}-7.5 \mathrm{~L} \mathrm{~min}^{-1} \mathrm{CO}_{2}$ ), respectively. Cooling of points 6,7 , and 8 down to $400^{\circ} \mathrm{C}$ from maximum temperatures



Fig. 5. Apparent temperature - time graph of T-fillet joint with $6 \mathrm{~mm}$ thickness welded with DMAG-6Ar-9CO $\mathrm{C}_{2}$ and $40 \% \mathrm{Ar}-60 \% \mathrm{CO}_{2}$ 


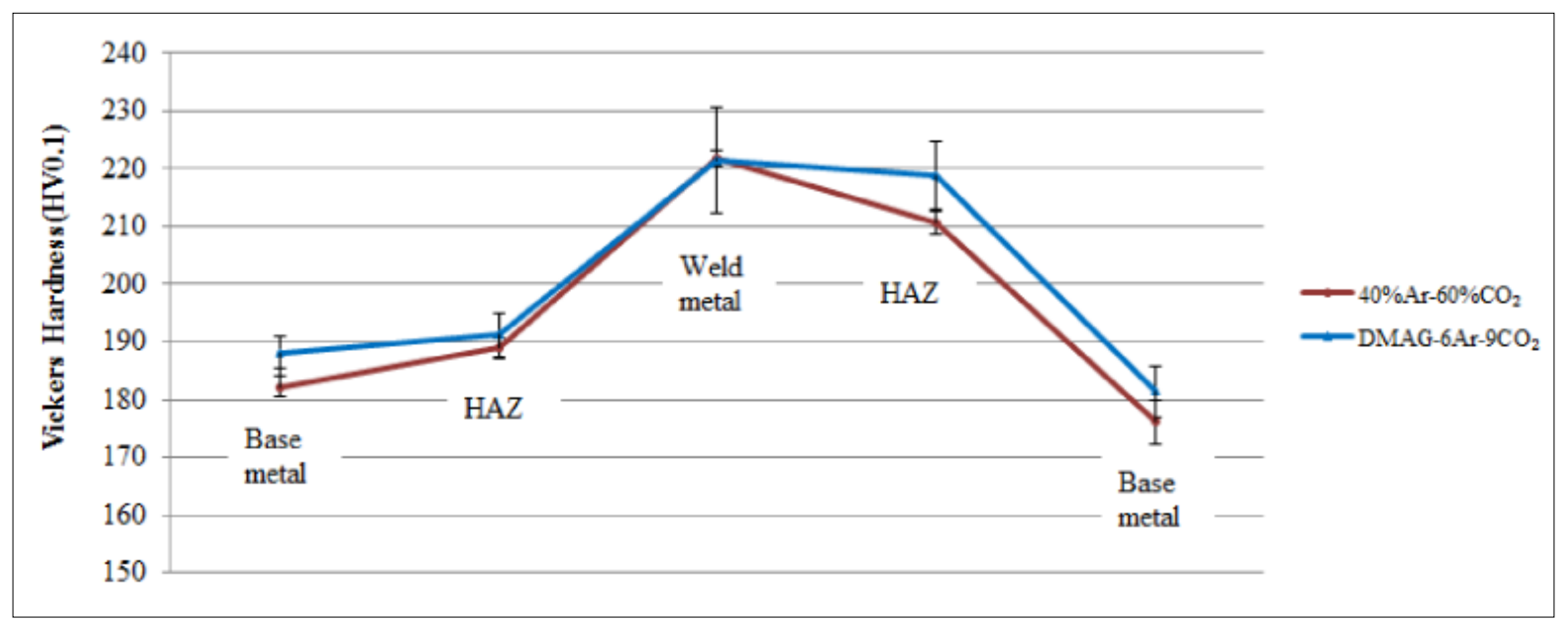

Fig. 6. Vickers hardness graph of T-fillet joint with $6 \mathrm{~mm}$ thickness welded with DMAG-6Ar-9CO $\mathrm{C}_{2}$ and $40 \% \mathrm{Ar}-60 \% \mathrm{CO}_{2}$



Fig. 7. Apparent temperature - time graph of T-fillet joint with $8 \mathrm{~mm}$ thickness welded with DMAG-7.5Ar-7.5CO $\mathrm{Cnd}_{2} 50 \% \mathrm{Ar}^{-50} \% \mathrm{CO}_{2}$

reached took $27.5 \mathrm{~s}, 22.2 \mathrm{~s}$ and $6.6 \mathrm{~s}$ with the use of traditional GMAW and $26.7 \mathrm{~s}, 23.3 \mathrm{~s}$ and $6.4 \mathrm{~s}$ with the use of DMAG, respectively. As a consequence, calculated cooling rates of these apparent temperature measurement points were $20.0^{\circ} \mathrm{C} \mathrm{s}^{-1}, 7.0^{\circ} \mathrm{C}$ $\mathrm{s}^{-1}$ and $1.8^{\circ} \mathrm{C} \mathrm{s}^{-1}$ with the use of conventional GMAW and $27.1^{\circ} \mathrm{C}$ $\mathrm{s}^{-1}, 9.0^{\circ} \mathrm{C} \mathrm{s}^{-1}$ and $3.9^{\circ} \mathrm{C} \mathrm{s}^{-1}$ with the use of DMAG, respectively.

Fig. 8 depicts Vickers hardness graph for T-fillet joints with $8 \mathrm{~mm}$ thickness welded with DMAG - 7.5 $\mathrm{L} \mathrm{min}^{-1} \mathrm{Ar}-7.5 \mathrm{~L}$ $\mathrm{min}^{-1} \mathrm{CO}_{2}$ and $50 \%$ Ar-50\%CO 2 . Measured weld metal and HAZ hardness values were higher with DMAG process. Since temperature measurement points reached higher temperatures with DMAG, austenite structure dissolved more elemental carbon. In addition to this, cooling rates were higher with DMAG. As a consequence, hardness values were considerably higher compared with conventional GMAW.

Fig. 9 presents apparent temperatures measured in T-fillet joint with $10 \mathrm{~mm}$ thickness, for points 6,7 and 8 were $1300^{\circ} \mathrm{C}$, $1133^{\circ} \mathrm{C}$ and $658^{\circ} \mathrm{C}$ with the use of traditional GMAW $(60 \% \mathrm{Ar}-$ $40 \% \mathrm{CO}_{2}$ ) and $888^{\circ} \mathrm{C}, 510^{\circ} \mathrm{C}$ and $394^{\circ} \mathrm{C}$ with the use of DMAG
(9 $\mathrm{L} \mathrm{min}^{-1} \mathrm{Ar}-6 \mathrm{~L} \mathrm{~min}^{-1} \mathrm{CO}_{2}$ ), respectively. Cooling of points 6 , 7, and 8 down to $400^{\circ} \mathrm{C}$ from maximum temperatures reached took $32.5 \mathrm{~s}, 35.7 \mathrm{~s}$ and $32 \mathrm{~s}$ with the use of traditional GMAW, respectively. Since apparent temperature for point 8 did not reach over $400^{\circ} \mathrm{C}$, cooling times only for points 6 and 7 were $29.6 \mathrm{~s}$, $23.8 \mathrm{~s}$ with the use of DMAG. As a consequence, cooling rates of these apparent temperature measurement points were $27.7^{\circ} \mathrm{C} \mathrm{s}^{-1}$, $20.5^{\circ} \mathrm{C} \mathrm{s}^{-1}$ and $8.1^{\circ} \mathrm{C} \mathrm{s}^{-1}$ with the use of conventional GMAW, respectively. Again cooling rates were $16.5^{\circ} \mathrm{C} \mathrm{s}^{-1}, 4.6^{\circ} \mathrm{C} \mathrm{s}^{-1}$ only for points 6 and 7 with the use of DMAG.

Fig. 10 shows Vickers hardness graph for T-fillet joints with $10 \mathrm{~mm}$ thickness welded with DMAG - $9 \mathrm{~L} \mathrm{~min}^{-1} \mathrm{Ar}-6 \mathrm{~L} \mathrm{~min}^{-1}$ $\mathrm{CO}_{2}$ and $60 \% \mathrm{Ar}-40 \% \mathrm{CO}_{2}$. It can be seen weld metal and $\mathrm{HAZ}$ hardness values were slightly higher with DMAG.

Table 3 presents weld metal, HAZ, base metal molten and filler metal molten area measurements for T-fillet joints with 6 $\mathrm{mm}, 8 \mathrm{~mm}$ and $10 \mathrm{~mm}$ thicknesses. HAZ and filler metal molten areas were bigger and base metal molten areas were smaller with the use of DMAG - $6 \mathrm{~L} \mathrm{~min}^{-1} \mathrm{Ar}-9 \mathrm{~L} \mathrm{~min}^{-1} \mathrm{CO}_{2}$ and 


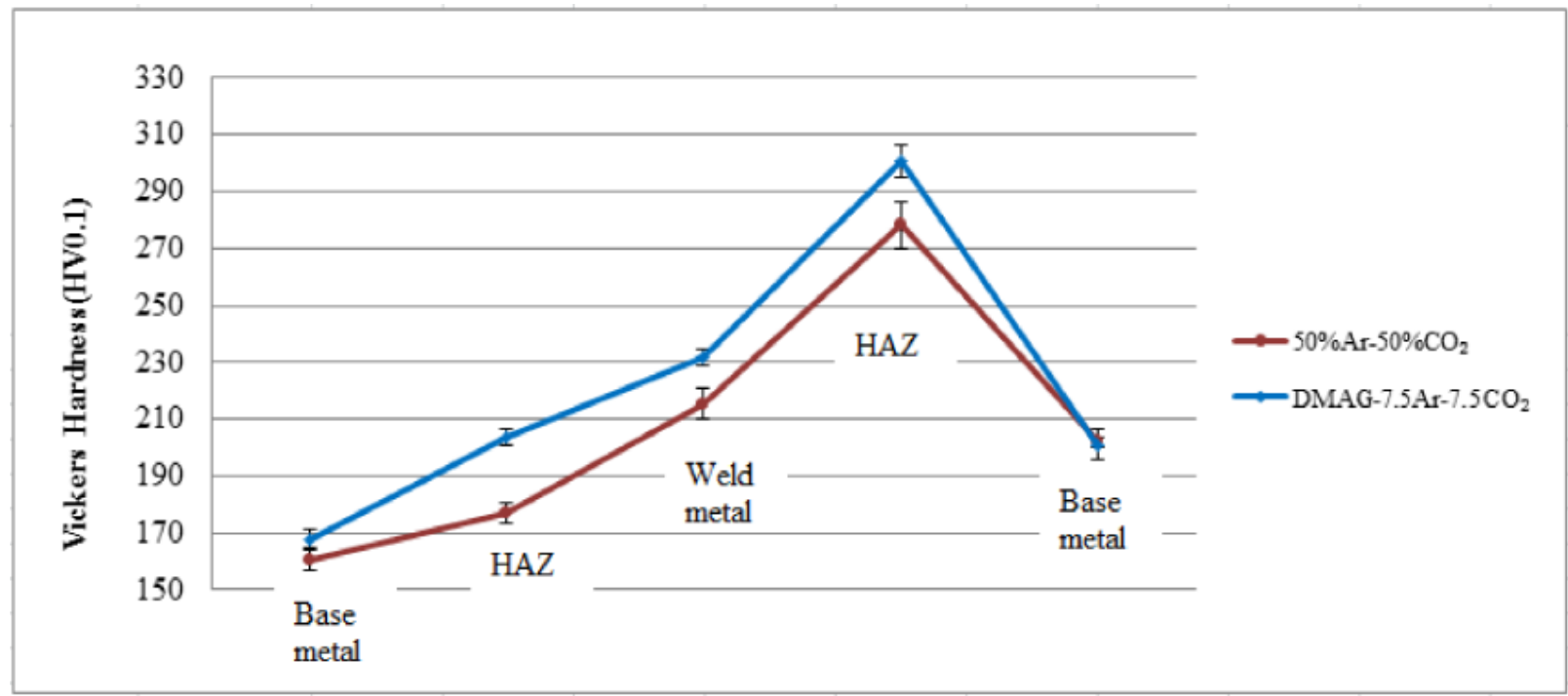

Fig. 8. Vickers hardness graph of T-fillet joint with $8 \mathrm{~mm}$ thickness welded with DMAG-7.5Ar-7.5CO $\mathrm{C}_{2}$ and $50 \% \mathrm{Ar}-50 \% \mathrm{CO}_{2}$

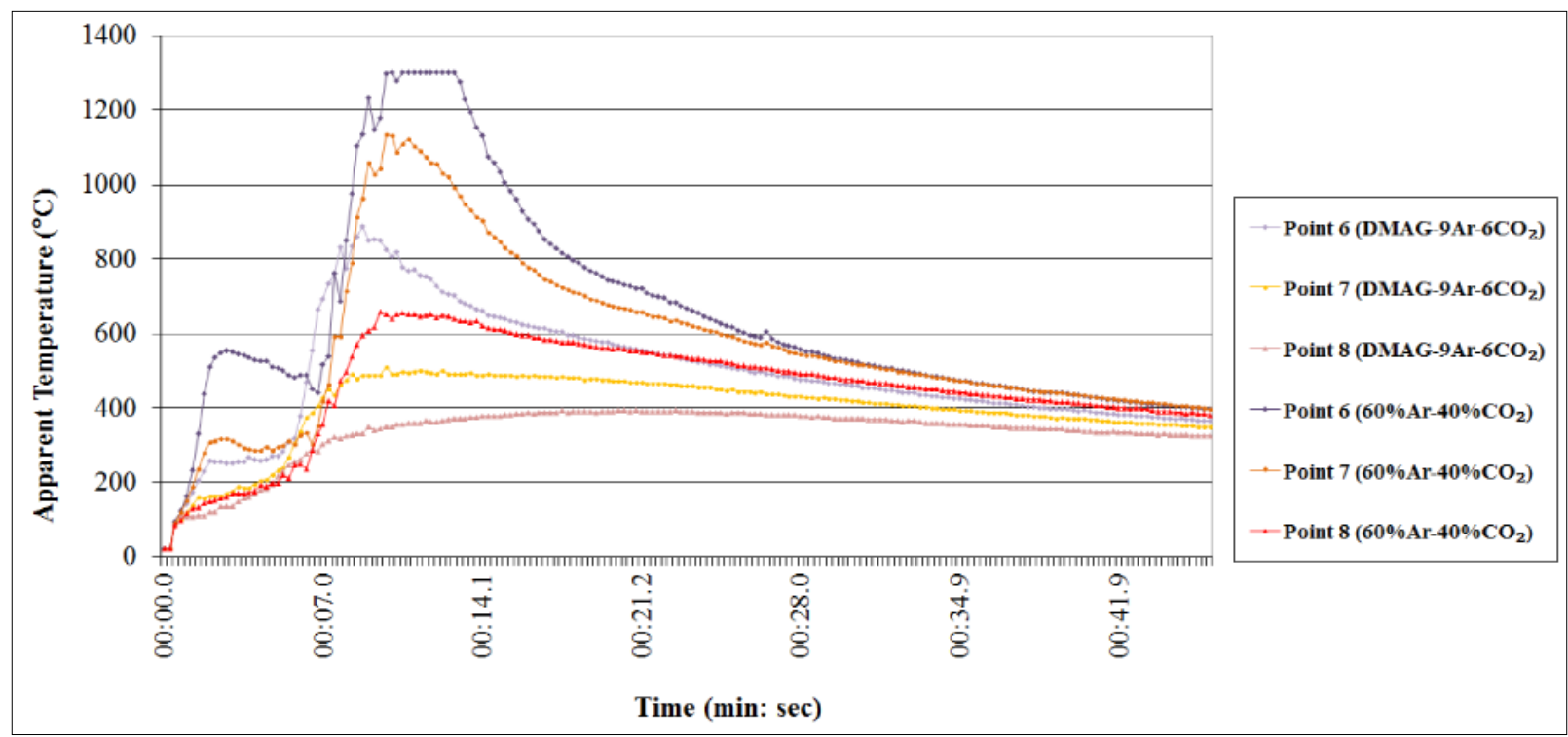

Fig. 9. Apparent temperature - time graph of T-fillet joint with $10 \mathrm{~mm}$ thickness welded with DMAG- $9 \mathrm{Ar}-6 \mathrm{CO}_{2}$ and $60 \% \mathrm{Ar}-40 \% \mathrm{CO}_{2}$

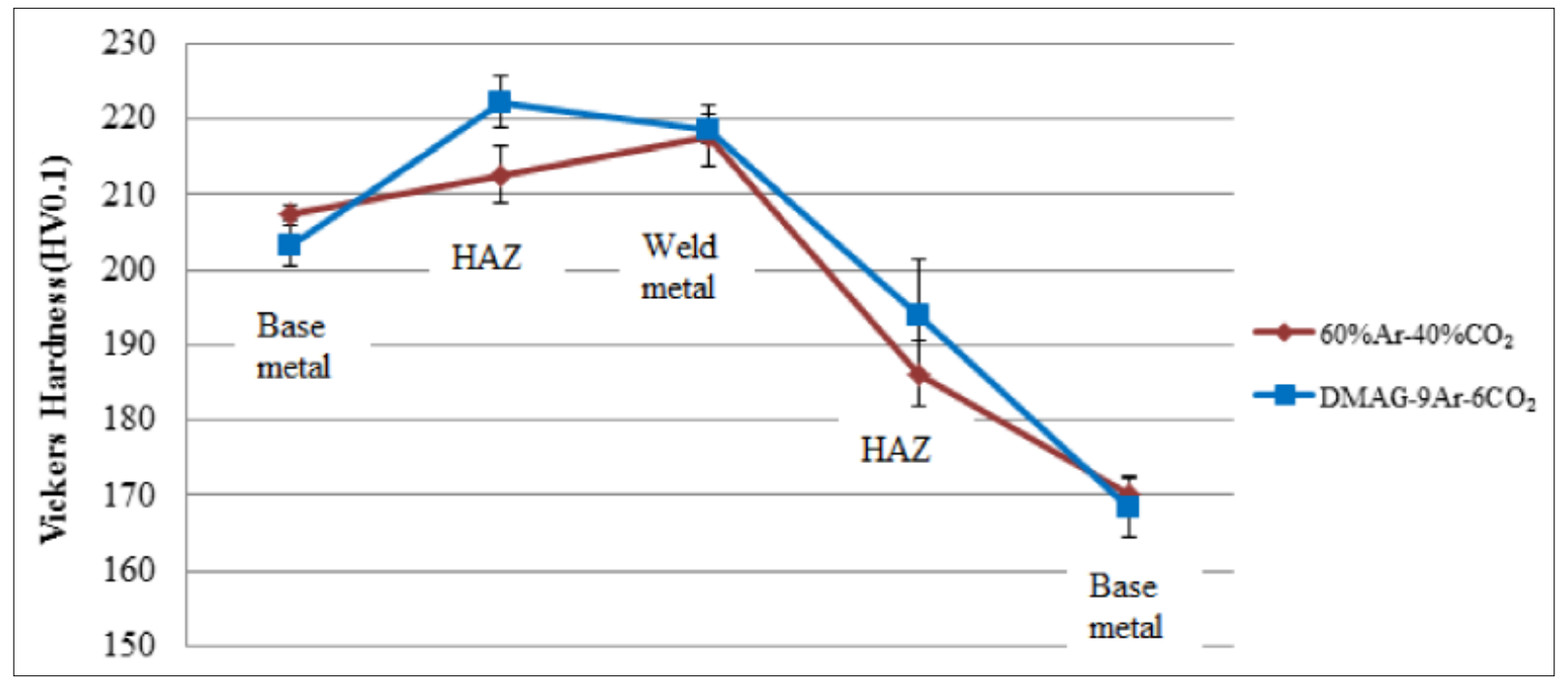

Fig. 10. Vickers hardness graph of T-fillet joint with $10 \mathrm{~mm}$ thickness welded with DMAG-9Ar- $6 \mathrm{CO}_{2}$ and $60 \% \mathrm{Ar}-40 \% \mathrm{CO}_{2}$ 
DMAG - 7.5 L min ${ }^{-1} \mathrm{Ar}-7.5 \mathrm{~L} \mathrm{~min}^{-1} \mathrm{CO}_{2}$ compared with corresponding conventional mix gas ratios. Filler metal molten area increased $14 \%$ with the use of DMAG with equal argon and $\mathrm{CO}_{2}$ ratios compared with traditional mix gas method. When argon was increased, it was observed HAZ area was smaller with the use of DMAG - $9 \mathrm{~L} \mathrm{~min}^{-1} \mathrm{Ar}-6 \mathrm{~L} \mathrm{~min}^{-1} \mathrm{CO}_{2}$ compared with traditional mix gas, $60 \% \mathrm{Ar}-40 \% \mathrm{CO}_{2}$. As observed in previous DMAG gas ratios, base metal molten area was smaller and filler metal molten area was bigger with the use of DMAG $-9 \mathrm{~L} \mathrm{~min}^{-1}$ $\mathrm{Ar}-6 \mathrm{~L} \mathrm{~min}^{-1} \mathrm{CO}_{2}$.

When weld metal microstructures of low carbon steel welded with different parameters using traditional GMAW and DMAG are compared, generally, finer and acicular structures are observed with DMAG. Whereas, microstructures obtained with conventional GMAW are generally coarser (Fig. 12, 14, 16).

When HAZs obtained with the use of both methods are compared, it is seen that microstructure is more homogenous and grains are smaller in size with the use of DMAG (Fig. 11, 13, 15).
TABLE 3

Mean weld metal, HAZ, base metal molten and filler metal molten area measurements in two-pass T-fillet joints with different thicknesses

\begin{tabular}{|c|c|c|c|c|c|}
\hline & $\begin{array}{l}\text { T-fillet Joint } \\
\text { Sample }\end{array}$ & 苞 & 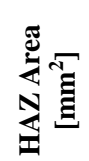 & 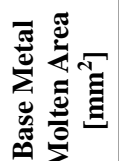 & 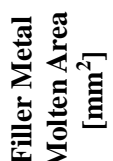 \\
\hline & $40 \%$ Ar- $60 \% \mathrm{CO}_{2}$ & 34.74 & 13.98 & 15.37 & 19.37 \\
\hline $\begin{array}{c}0 \\
\mathrm{~mm}\end{array}$ & 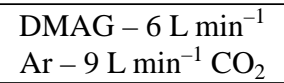 & 33.14 & 16.49 & 13.23 & 19.91 \\
\hline & $50 \%$ Ar- $50 \% \mathrm{CO}_{2}$ & 41.39 & 17.40 & 17.13 & 24.26 \\
\hline $\begin{array}{c}8 \\
\mathrm{~mm}\end{array}$ & $\begin{array}{l}\text { DMAG - 7.5 L min } \\
\text { Ar }-7.5 \mathrm{~L} \mathrm{~min}^{-1} \mathrm{CO}_{2}\end{array}$ & 35.07 & 18.59 & 7.37 & 27.70 \\
\hline & $60 \% \mathrm{Ar}-40 \% \mathrm{CO}_{2}$ & 57.70 & 33.55 & 21.20 & 36.50 \\
\hline $\begin{array}{c}10 \\
\mathrm{~mm}\end{array}$ & $\begin{array}{l}\text { DMAG - } 9 \mathrm{~L} \min ^{-1} \\
\mathrm{Ar}-6 \mathrm{~L} \mathrm{~min}{ }^{-1} \mathrm{CO}_{2}\end{array}$ & 58.06 & 30.80 & 20.23 & 37.83 \\
\hline
\end{tabular}
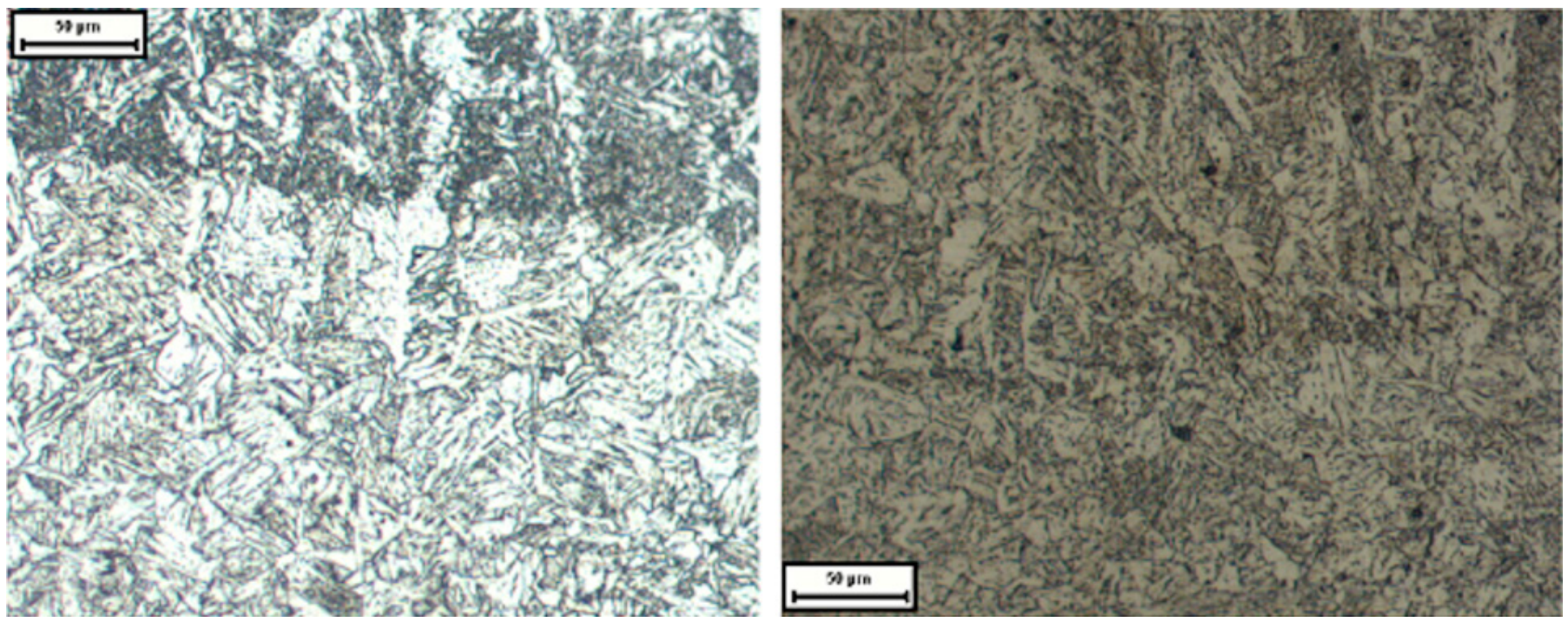

Fig. 11. HAZ micrographs (200×) of DMAG - $6 \mathrm{~L} \mathrm{~min}{ }^{-1} \mathrm{Ar}-9 \mathrm{~L} \mathrm{~min}{ }^{-1} \mathrm{CO}_{2}$ (left) and $40 \% \mathrm{Ar}-60 \% \mathrm{CO}_{2}$ (right)
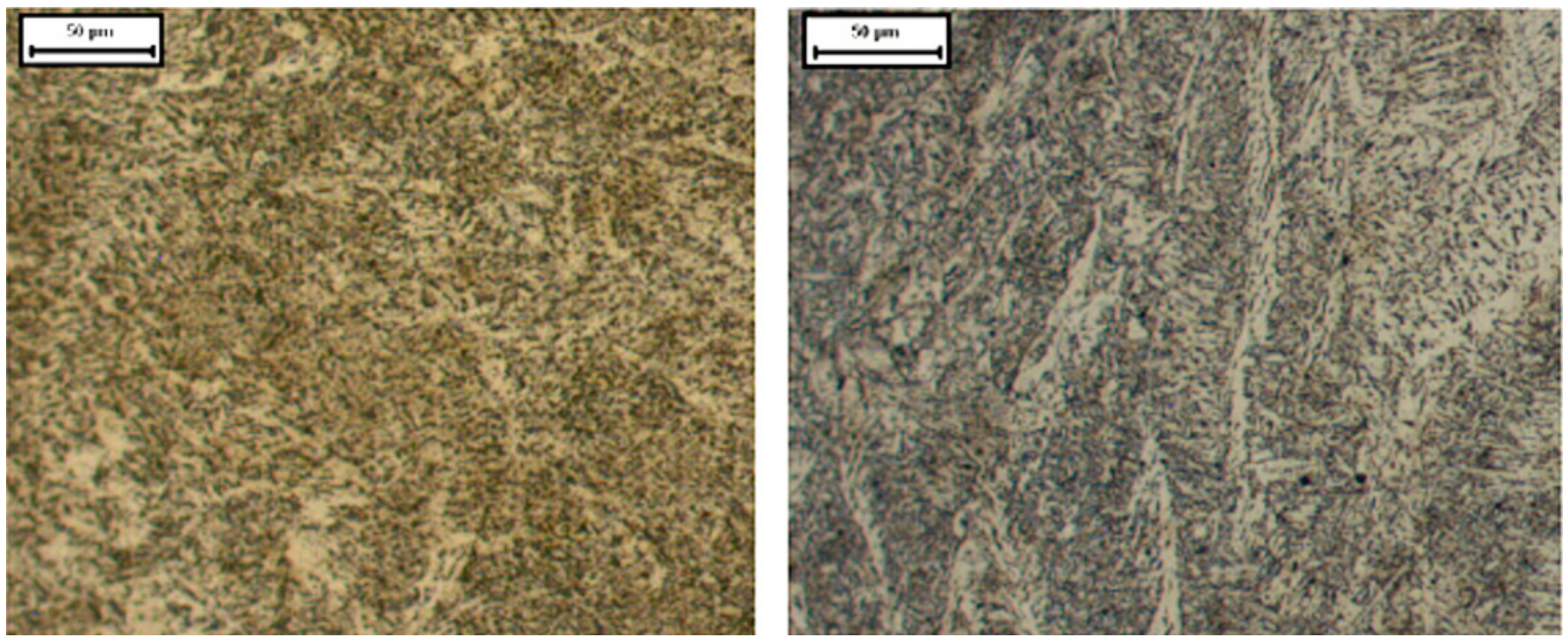

Fig. 12. Weld metal micrographs (200×) of DMAG - $6 \mathrm{~L} \mathrm{~min}^{-1} \mathrm{Ar}-9 \mathrm{~L} \mathrm{~min}{ }^{-1} \mathrm{CO}_{2}$ (left) and $40 \% \mathrm{Ar}-60 \% \mathrm{CO}_{2}$ (right) 

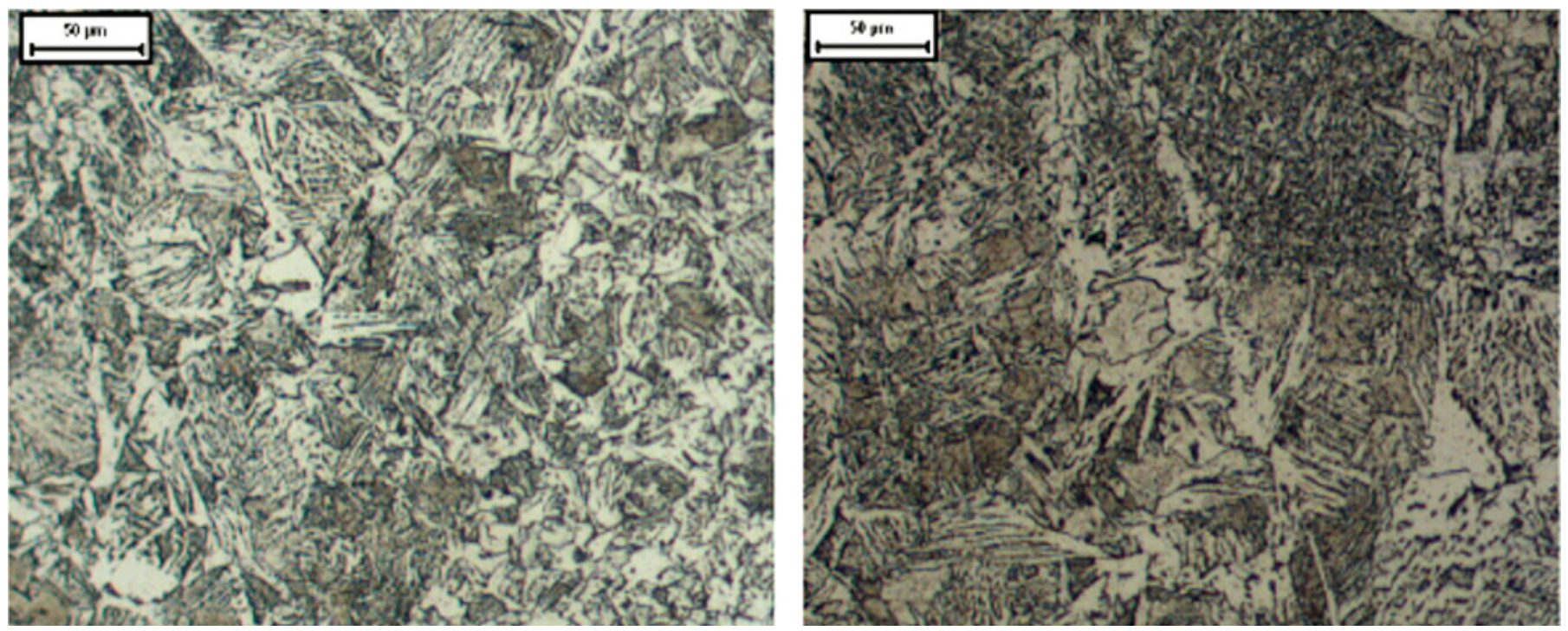

Fig. 13. HAZ micrographs (200×) of DMAG - 7.5 $\mathrm{L} \mathrm{min}^{-1} \mathrm{Ar}-7.5 \mathrm{~L} \mathrm{~min}^{-1} \mathrm{CO}_{2}$ (left) and $50 \% \mathrm{Ar}-50 \% \mathrm{CO}_{2}$ (right)
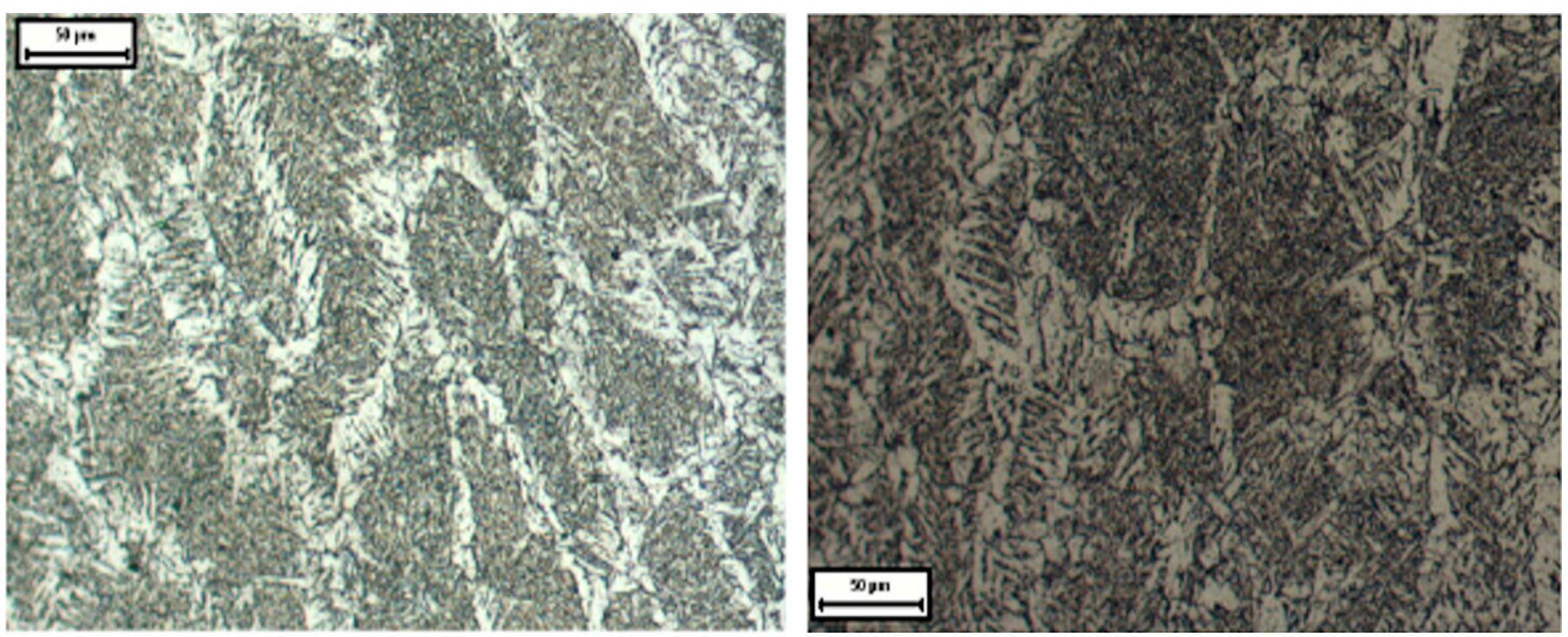

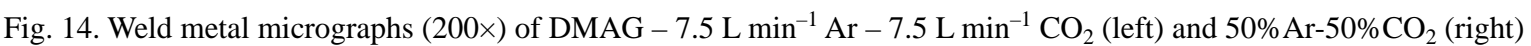
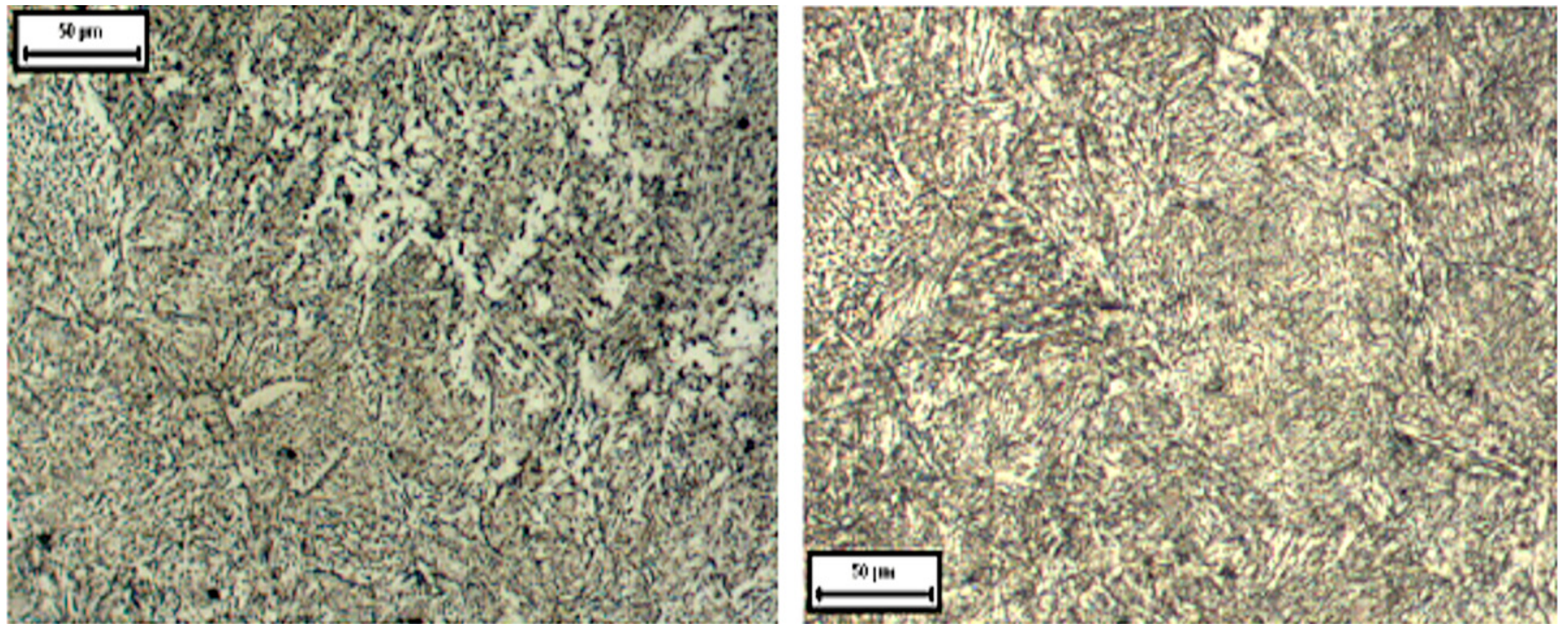

Fig. 15. HAZ micrographs (200×) of DMAG - $9 \mathrm{~L} \mathrm{~min}{ }^{-1} \mathrm{Ar}-6 \mathrm{~L} \mathrm{~min}{ }^{-1} \mathrm{CO}_{2}$ (left) and $60 \% \mathrm{Ar}-40 \% \mathrm{CO}_{2}$ (right) 

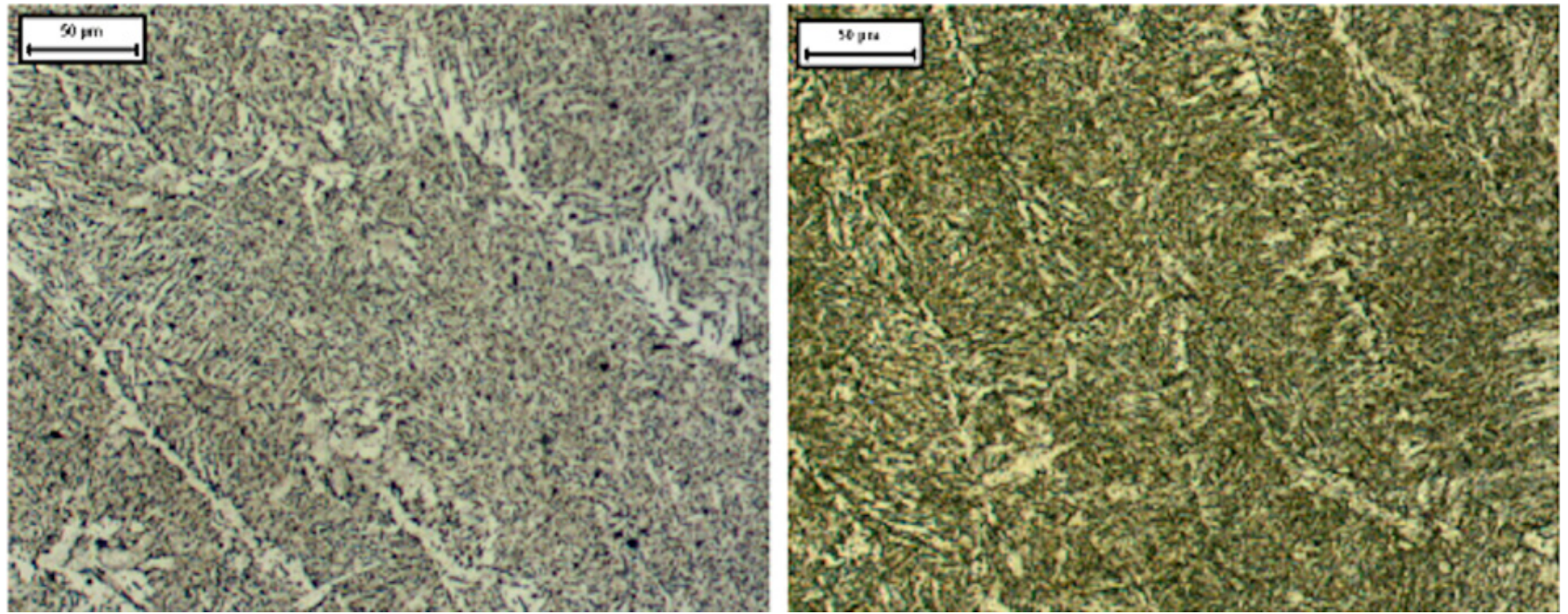

Fig. 16. Weld metal micrographs (200×) of DMAG - $9 \mathrm{~L} \mathrm{~min}^{-1} \mathrm{Ar}-6 \mathrm{~L} \mathrm{~min}^{-1} \mathrm{CO}_{2}$ (left) and $60 \% \mathrm{Ar}-40 \% \mathrm{CO}_{2}$ (right)

\section{Conclusions}

Conclusions drawn from this study can be summarized as follows;

1. When filler metal molten area increased, base metal molten area decreased in DMAG of low carbon steel (Table 3). This provides welding of low carbon steels using DMAG method with higher speeds. Thus, especially in T-fillet welding with DMAG would allow rise in welding speed with regard to weld bead geometry desired in standards.

2. Finer and more homogenous grains observed with DMAG. This result is parallel with the hardness values. Although micrographs of weld beads and HAZs of the welds obtained with the use of both methods involve differences, since carbon content of the base metal is low ( $0.1 \%)$, there are no significant discrepancies in hardness distributions.

\section{Acknowledgements}

This study has been supported by Yildiz Technical University Scientific Research Projects Coordinatorship (Project no: 29-06-01-04). Authors also would like to acknowledge Dr. Izzet Turkocagi of Sekon Kaynak Co. for helping design and manufacture double channel shielding gas torch and Mr. Can Odabas of Kaynak Teknigi (Askaynak) Co. for providing welding power source, welding wires and shielding gases.

\section{REFERENCES}

[1] T. Mert, N. Gultekin, A. Karaaslan, Mater. Test. 57, 91 (2015).

[2] T. Mert, N. Gultekin, A. Karaaslan, Adv. Mech. Eng. Article ID 371212, (2015). doi: 10.1155/2014/371212

[3] D. Li, S. Lu, W. Dong, D. Li, Y. Li, J. Mater. Process Tech. 212, 128 (2012).

[4] D. Li, S. Lu, D. Li, Y. Li, J. Mater. Sci. Technol. 30, 922 (2014). doi:10.1016/j.jmst.2013.12.012

[5] D. Li, S. Lu, D. Li, Y. Li, J. Mater. Sci. Technol. 30, 172 (2014).

[6] D. Li, S. Lu, D. Li, Y. Li, Adv. Mat. Res. Vols. 97-101, 3978 (2010).

[7] S. Lu, H. Fujii, K. Nogi, J. Mater. Sci. Technol. 26, 170 (2010)

[8] I. Masumoto, M. Kutsuna, M. Abraham, Trans. Jpn. Weld. Soc. 19, 38 (1988).

[9] M. Kutsuna, M. Abraham, Trans. Jpn. Weld. Soc. 20, 45 (1989).

[10] M. Kutsuna, M. Abraham, Y. Kotani, K. Yamawaki, D. Hayashi, IIW Doc. No. XII-1485-97, 65 (1997).

[11] T. Mert, N. Gultekin, S. Yumurtaci, Y.T.U. Sigma J. Eng. Nat. Sci. 31, 363 (2013). (in Turkish)

[12] R. Killing, Weld Cut. 36, E148 (1984).

[13] D. Böhme, H. Heuser, Weld Cut. 40, E25 (1988). 